\title{
ASPECTS ON THE INFLUENCE OF STARTING THE OWN SERVICES CONSUMERS OF AN ENERGY GROUP WITH UNIT OF 330 MW ON THE POWER SUPPLY
}

\author{
Cristinel POPESCU*, Cornel HAȚIEGAN**, Cristinel RACOCEANU*, \\ Andreea Cristina BEJINARIU*** \\ *,Constantin Brâncuși” University of Târgu Jiu, Romania, \\ **,Eftimie Murgu” University of Reșița, Romania, \\ *** Politehnica University of Timisoara, Romania \\ cristi67pop@yahoo.com, c.hatiegan@uem.ro, c_racoceanu@yahoo.com \\ bejinariu_andreea_cristina@yahoo.com
}

\begin{abstract}
The elaborated paper had as support a study case on the monitoring of the supply voltage on a busbar system, which feeds the electric motors that enters into the configuration of the technological flow of electricity production of an energy group with a unitary power of $330 \mathrm{MW}$. In the start-up phase of the energy groups with a unitary power of $330 \mathrm{MW}$, the consumers of their own services are supplied with electricity by means of general service transformers interconnected to the National Energy System.
\end{abstract}

Keywords: power supply, own services, bus bars, main bus systems, monitoring, energy group

\section{Introduction}

Considering that, in the start-up phase of an energy group with a unitary power of $330 \mathrm{MW}$, the consumers of own services are fed from the National Energy System, according to the norms in force, it is necessary to monitor the supply voltage [17]. The electricity supply of the consumers of own services, afferent to an energy group with a unitary power of $330 \mathrm{MW}$, is made in the starting phase of the group, from the National Power System through a system of collector bars, known as "main bars" [8-10]. The main busbar system provides electrical power supply from the operator's electrical network distribution through a general service electrical transformer, with a nominal power of 40 MVA and a $110 / 6 \mathrm{kV}$ transformation ratio.
In the start-up phase of an energy group with a unitary power of $330 \mathrm{MW}$, the electricity supply of consumers of own services is realized through the main busbar system, so that after starting the group and entering it in parallel with the National Energy System, it will switch the power supply with electricity from a block own service transformer [5]. As it can be seen from Figure 1, the block proprietary service transformer is connected to the 330 MW synchronous generator terminals via a busbar system $[8,9]$.

Considering the fact that in the configuration of a thermoelectric power plant there are several energy groups, in order to ensure the autonomy of each group's operation, it is necessary to use a own services transformer for each of them. 
The "bus" busbar system is arranged alongside the power plant to facilitate the connection of its own service consumers afferent to all energy groups $[8,11]$.

In order to assure the power demanded by own services users of the energy groups in the start-up phase, this busbar system is powered by two or more general service transformers and is longitudinally sectioned by means of longitudinal coupling switches.

Passing the power supply of electricity of the consumers of own services, from the general services transformer to the own block services transformer, is made available to the operative management step within the power plant, following the connection of the energy group in parallel with the National Energy System.

Considering that in the start-up phase of the energy groups within the power plant, the power supply is made from the network operator's electrical distribution network and the delimitation point is the $110 \mathrm{kV}$ part of the general service transformer, the compliance with the quality parameters upstream with the delimitation point is mandatory. In this regard, the elaborated paper had in view the monitoring of the supply voltage of the customers of own block block services, in the starting phase (figure 1) [12].

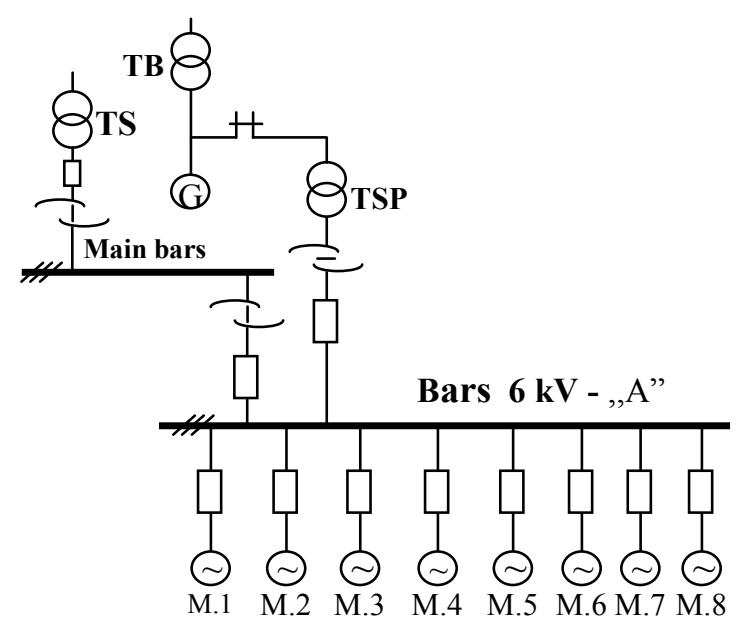

Figure 1. The electric power scheme of own services consumers of medium voltage
2. Determination of voltage on the collector bar system

Both the consumption of electricity and its production are conditioned by the existence of electrical installations and equipment that enter within the configuration of a certain well-defined technological flow, which must be within the quality parameters of electricity (continuity in power supply, Voltage variation, non-symmetry). The values of the quality parameters of the electricity taken from the electricity distribution network of the operator are regulated by the Performance Standards. Fitting in the values set by these standards is conditioned by the state of operation of the electrical equipment and devices that are in the configuration of the technological flow schemes. Accordingly, a permanent monitoring of the state of operation of these equipment is required, through a technical diagnosis regulated by the technical regulations in force. The monitoring of the supply voltage of the main busbar system in the startup phase was carried out using a CA 8352 voltage analyzer (figure 2), [13].

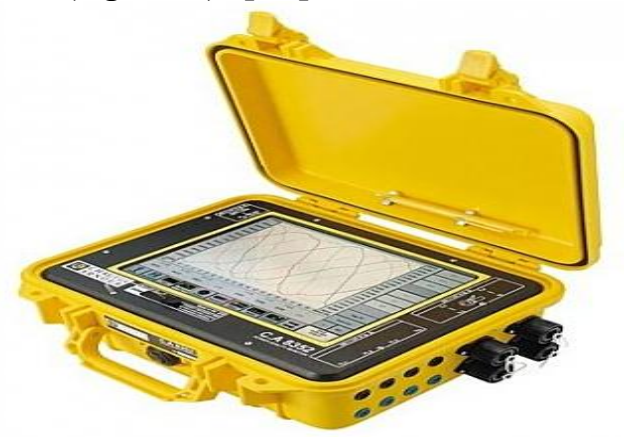

Figure 2. Voltage Analyzer-CA 8352

From the monitoring diagrams of the harmonics, corresponding to the transient regimes characteristic to the starting of the medium voltage consumers entering in the configuration of the technological flow diagram of the power generation of a 330 MW energy group, it can be observed that on phase $\mathrm{R}$ of the main busbar system it was recorded a voltage drop across the $\mathrm{R}$ phase from $3600 \mathrm{~V}$ to $3300 \mathrm{~V}$ (Fig. 3). Similarly, on phase $\mathrm{R}$ there was also a 
voltage drop from $3600 \mathrm{~V}$ to $3200 \mathrm{~V}$ [1417].

The value of the voltage fluctuation, generated by the simultaneous start of several own services consumers or the start of a relatively high nominal power consumer, can be determined with the following relation [8]:

$\Delta \mathrm{V}_{\mathrm{f}}=\left(\mathrm{U}_{\max }-\mathrm{U}_{\min }\right) / \mathrm{U}_{\mathrm{N}} \cdot 100[\%]$

Referring to the values recorded by the voltage analyzer it will result:

$\Delta \mathrm{V}_{\mathrm{f}}=(3600-300) / 3600 \cdot 100=300 / 3600 \cdot 100$ $\Delta \mathrm{V}_{\mathbf{f}}=8,33[\%]$

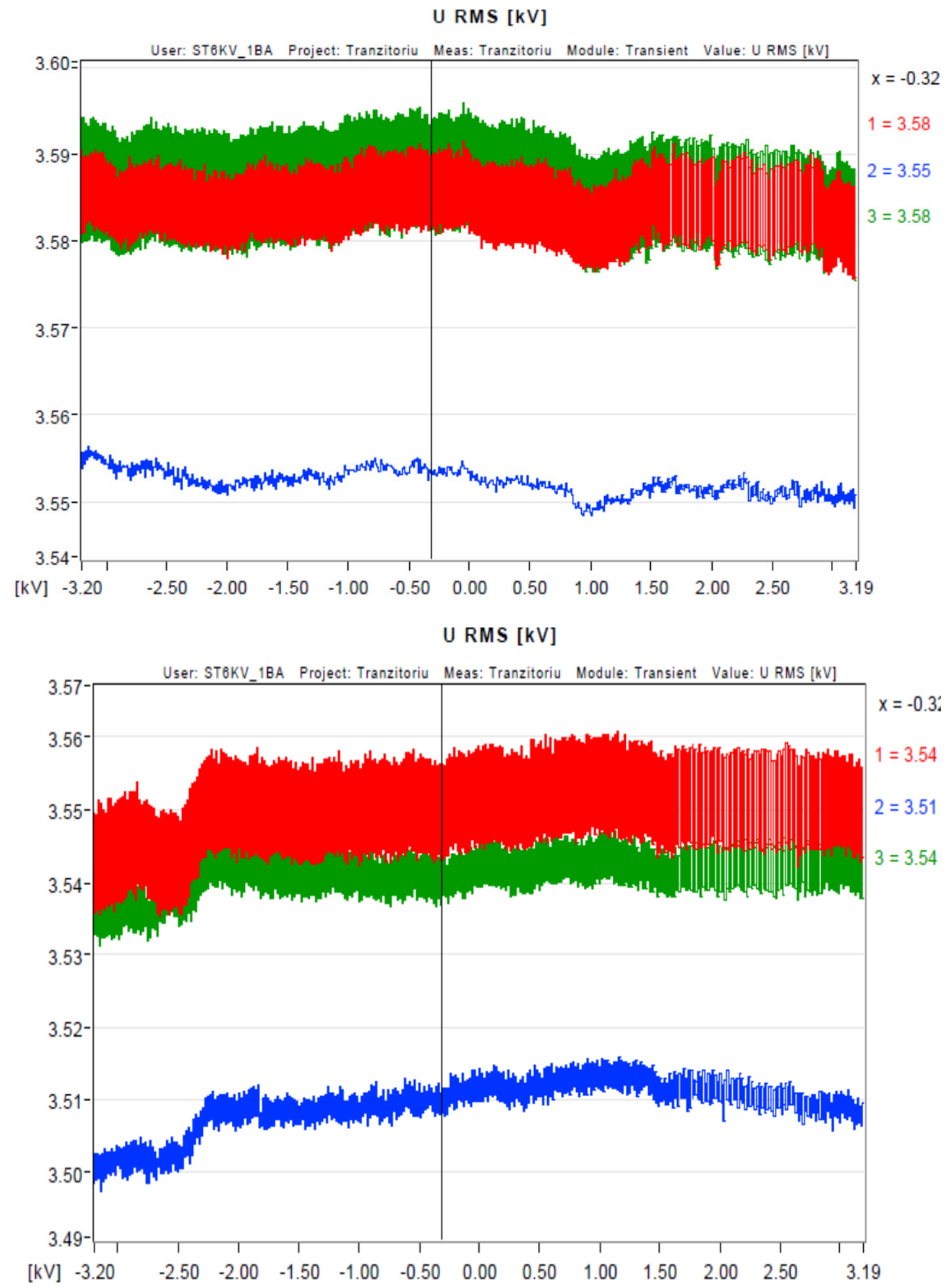


U RMS [kV]
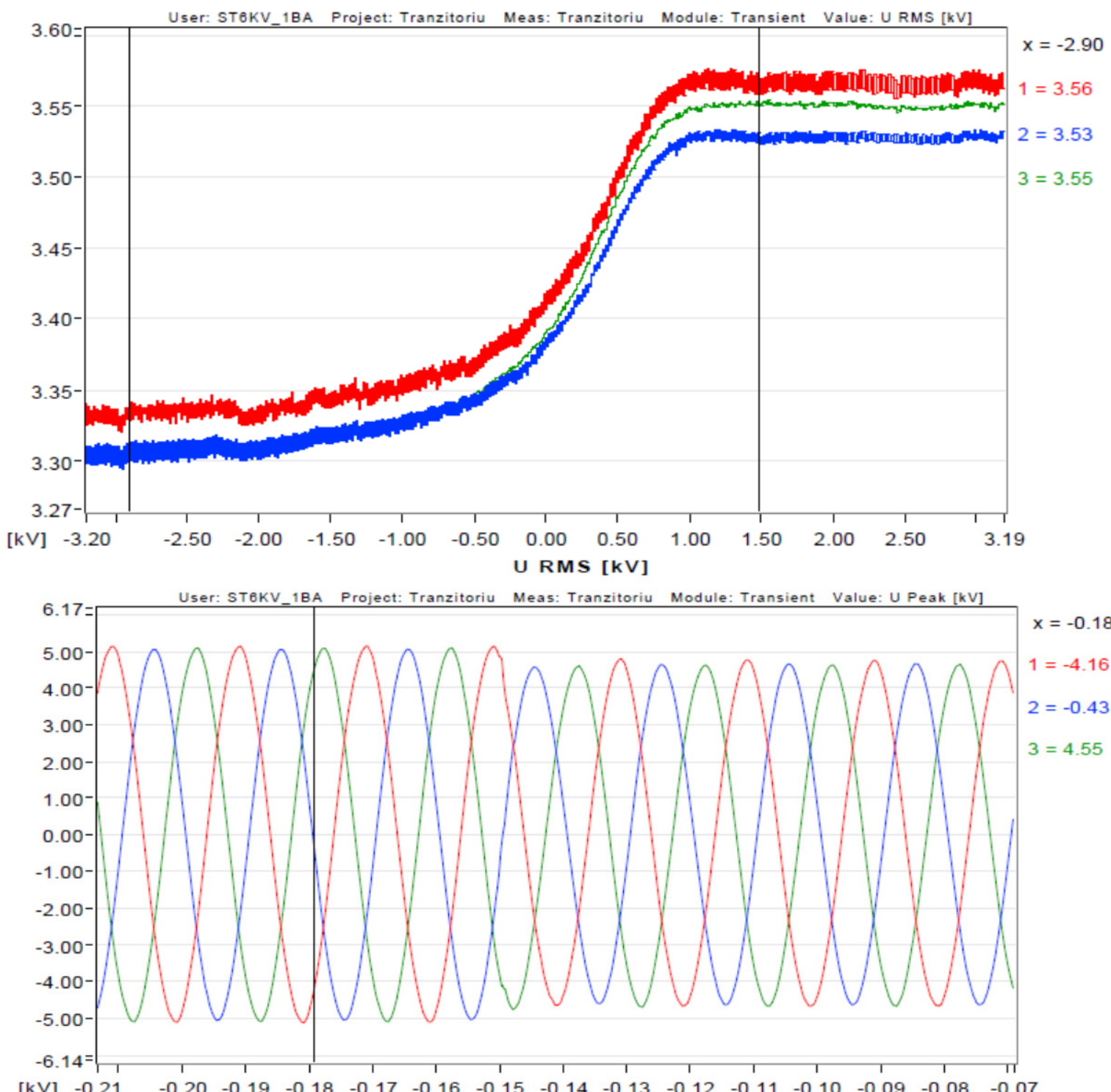

U RMS [kV]

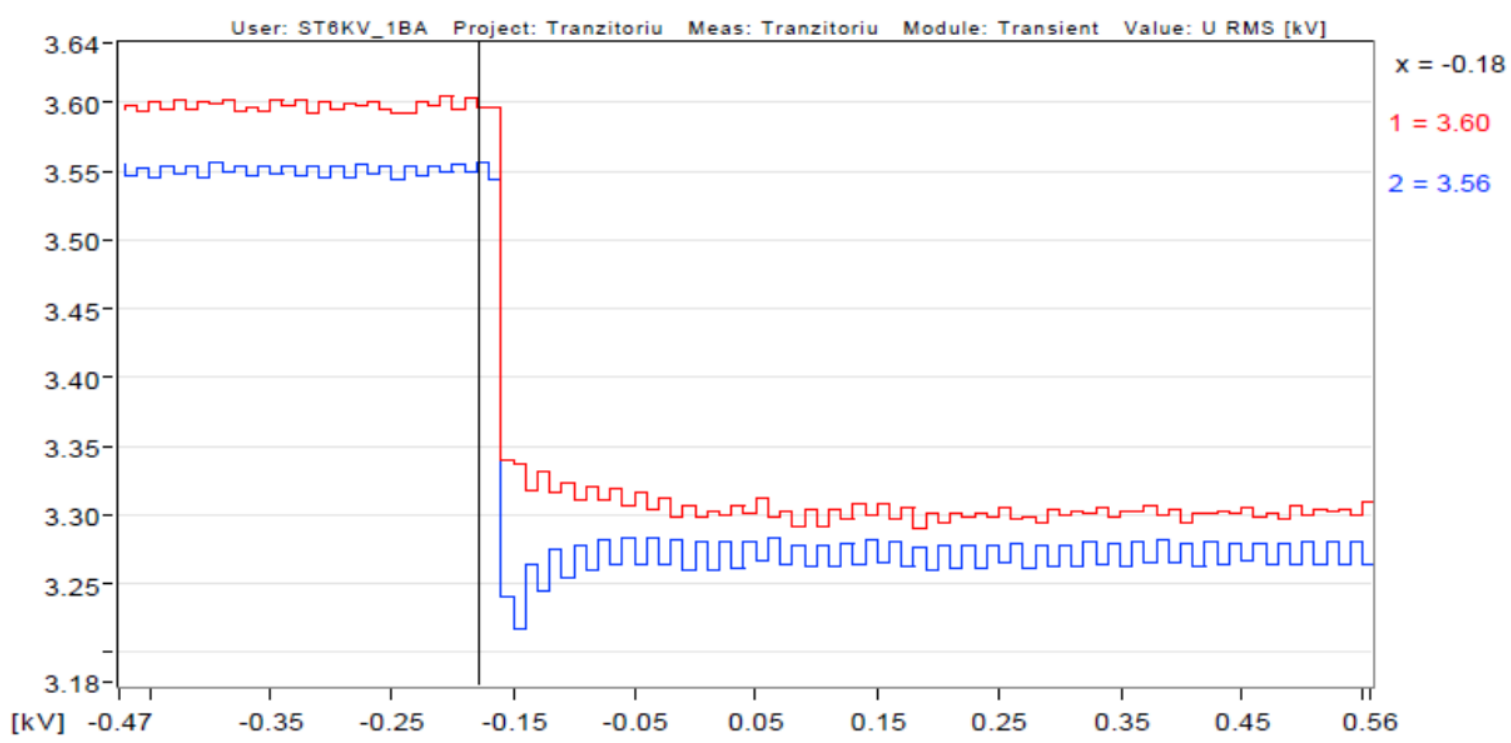




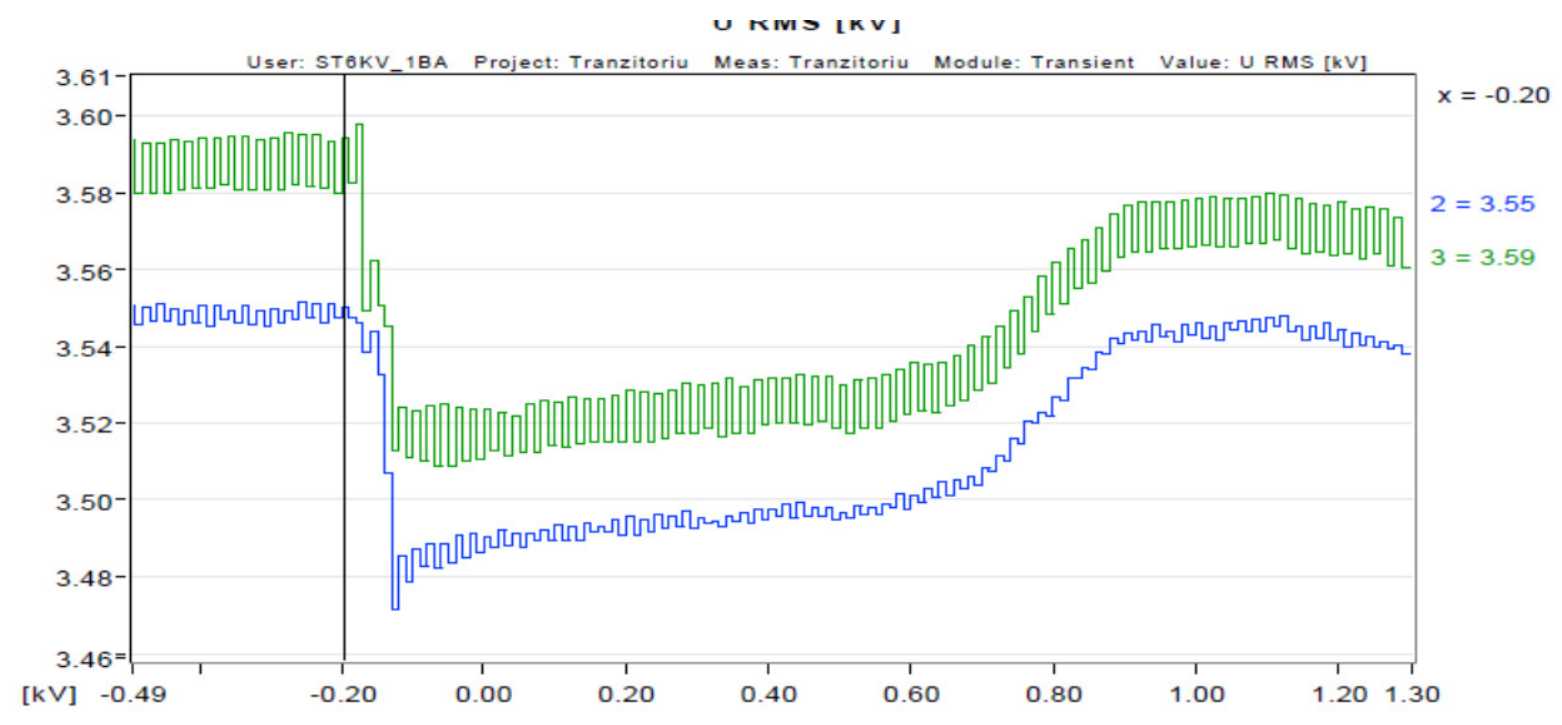

Figure 3. Graphs of voltage variation of medium voltage electrical consumers

Figure 3 shows some diagrams illustrating the variation of phase voltages on the bus bars, the variations generated by the startup of own service consumers whose power exceeds $1000 \mathrm{~kW}$.

The selected graphs resulted from realtime measurements at certain time intervals and during the starting period of a 330 MW power group. As can be seen from the graph shown in Figure 3, the voltage variations between 3 power phases (1,2 and 3$)$ are equally sensitive $(3,56 \mathrm{kV}$ $3,53 \mathrm{kV}-3,55 \mathrm{kV}, 3,54 \mathrm{kV}-3,51 \mathrm{kV}-$ $3,54 \mathrm{kV}, 3,58 \mathrm{kV}-3.55 \mathrm{kV}-3.58 \mathrm{kV}$ ), which means that the system is balanced. It should be noted that, at certain times, there are relatively large variations in voltage (sometimes at the permissible limit) caused by the starting of electric motors with high power units, of which it is worth noting the electric motor of the power pump With boiler water, a power of $7200 \mathrm{~kW}$.

\section{Conclusions}

Following the monitoring of the supply voltage on the main bars through which the medium voltage consumers are supplied, in the start-up phase of an energy group with a unitary power of $330 \mathrm{MW}$, the following can be concluded:

1. As a result of the start-up of own services customers related to a $330 \mathrm{MW}$ energy group, transient regimes may occur on the main bars, which have the effect of slow voltage variations and voltage fluctuations.

2. The slow voltage variations, caused by the start of the own service consumers, fall within the limit values $\pm 10 \%$.

3. At the concomitant start-up of several own services consumers or of a relatively large unit power consumer, a transient regime may occur for which the gradient $\Delta \mathrm{U} / \Delta \mathrm{t}$ is greater than $1 \% /$ second, which is characteristic to a fluctuation of voltage.

\section{References}

[1] SR EN 50160 - Caracteristici ale tensiunii furnizate de reţelele publice de distribuţie

[2] NTE 012/14/00-Norma tehnică energetică pentru limitarea fluctuațiilor de tensiune, inclusiv a efectului de flicker, în rețelele electrice de transport și de distribuție

[3] Ordinul ANRE nr.28/2007-Standard de performanţă pentru serviciul de distribuţie a energiei electrice

[4] IEEE 519-1992 - Standard de descriere a nivelelor de armonici acceptate în punctele de delimitare între furnizor şi consummator 
[5] Cornel Haţiegan, Ioan Padureanu, Marcel Romulus Jurcu, Marius Biriescu, Mihaela Răduca, Flaviu Dilertea, The evaluation of the insulation performances of the stator coil for the high power vertical synchronous hydro-generators by monitoring the level of partial discharges, Electr Eng, 08 November 2016.

[6] C Haţiegan, I Pădureanu, M Jurcu, MD Nedeloni, CO Hamat, CP Chioncel, S Trocaru, O Vasile, O Bădescu, D Micliuc, L Filip Nedeloni, A Băra, L (Barboni) Haţiegan, Vibration analysis of a hydro generator for different operating regimes, IOP Conference Series: Materials Science and Engineering, Hunedoara, Volumul 163, Nr.1, 2016.

[7] C Haţiegan, CP Chioncel, E Răduca, C Popescu, I Pădureanu, MR Jurcu, D Bordeaşu, S Trocaru, F Dilertea, O Bădescu, IM Terfăloagă, A Băra, L (Barboni) Haţiegan, Determining the operating performance through electrical measurements of a hydro generator, IOP Conference Series: Materials Science and Engineering, Hunedoara, Volumul 163, Nr.1, 2016.

[8] Grup energetic cu puterea unitară de 330 MW - Instrucțiuni de exploatare

[9] Cristinel Popescu, Cornel Hatiegan, Aspects regarding the Calculation of the Dielectric Loss Angle Tangent between the Windings of a Rated 40 MVA Transformer, Analele Universităţii "Eftimie Murgu", Fascicula de Inginerie, Anul XXII, Nr. 2, Reşiţa, 2015.

[10] Cornel Haţiegan, Ioan Hălălae, Cristinel Popescu, Nicoleta Gillich, Luminiţa (Barboni) Haţiegan, Eugen Răduca, Lidia (Filip) Nedeloni, Evaluation Insulation of the Stator Coil A Hydro-Generators Through Monitoring the Level of Partial Discharges, National Scientific Conference with International Participation "Confereng 2016", Targu-Jiu, November 4-5, Annals of „Constantin Brâncuşi”” University of Târgu Jiu, Nr. 3., Pp. 5762, 2016.

[11] Novăcescu F., Haţiegan C., Răduca M., Răduca E., Pop N., Nedeloni M., A New Method for Testing the No-Load Work of an Electric One-Phase Transformer Using The Graphical Programming, Scientific Bulletin of "Politehnica" University of Timişoara, vol. 57 (71) 2, 2012.

[12] Ion Mircea - Instalații și echipamente electrice, Editura Didactică și Pedagogică, București,1996.

[13] Analizor CA 8352 - Fișa tehnică

[14] Contract de cercetare -Studiu privind regimul tranzitoriu al tensiunilor şi curenţilor pe staţia de $6 \mathrm{kV}$, în diferite scheme de alimentare a unei centrale termoelectrice

[15] Ioan Pădureanu, Marcel Jurcu, Ladislau Augustinov, Cornel Haţiegan, Eugen Răduca, Laurenţiu Pădeanu, Optimisation of the Start-up and Operation Regimes of Cooling Water Pumps of a High-Power Hydro Generator, Analele Universităţii "Eftimie Murgu", Fascicula de Inginerie, Anul XXII, Nr. 1, Reşiţa, 2015.

[16] Ioan Pădureanu, Marcel Jurcu, Ladislau Augustinov, Cornel Haţiegan, Eugen Răduca, Implementation of an Automatic System for the Monitoring of Start-up and Operating Regimes of the Cooling Water Installations of a Hydro Generator, Analele Universităţii "Eftimie Murgu", Fascicula de Inginerie, Anul XXII, Nr. 1, Reşiţa, 2015.

[17]Marcel Romulus Jurcu, Ioan Padureanu, Laurentiu Padeanu, Ladislau Augustinov, Cornel Hatiegan, Tests Regarding the Transitory Regimes of Putting off Load of the Hydroagregate, Analele Universităţii "Eftimie Murgu", Fascicula de Inginerie, Anul XXII, Nr. 2, Reşiţa, 2015. 